\title{
Legal activity of an individual in criminal law and environmental policy
}

\author{
Alexey Sumachev ${ }^{1,2, *}$, Sergey $\mathrm{Kvach}^{2}$, Dmitriy Dyadkin ${ }^{3}$, Olga Arkhipova ${ }^{4}$ \\ ${ }^{1}$ Academy of the Federal penitentiary service of Russia, Sennaya str., 1, Ryazan, 390000, Russia \\ ${ }^{2}$ Ugra State University, Chekhov str., 16, Khanty-Mansiysk, 628012, Russia \\ ${ }^{3}$ Surgut State University, Lenin Avenue, 1, Khanty-Mansiysk Autonomous Okrug-Yugra, Surgut, \\ 628412, Russia \\ ${ }^{4}$ Tyumen Industrial University, Volodarskogo str., 38, Tyumen, 625000, Russia
}

\begin{abstract}
Criminal law is traditionally viewed as a branch of public law. Until recently, the category of "dispositivity" in the Russian theory of criminal law had not even been considered. However, it is argued that the development and reflection of dispositivity fundamentals in the criminal law shows the level of protection of law-abiding citizens and also serves as an indicator of activity of legal subjects in the field of criminal justice. The article attempts to define the concept of dispositivity in criminal law and explores its theoretical and applied aspects through conceptual (political and legal) and instrumental approaches. As a part of the conceptual (political and legal) approach, dispositivity is treated as the common grounds of the field of legal regulation. As a part of the instrumental approach, dispositivity is regarded as a method of legal regulation, property legal norms, as well as the mode of legal regulation. From the point of legal methodology, we can speak of dispositivity in the Russian criminal law, since there are no "pure" or distinct fields of private or public law. Simultaneously with the imperative method of legal regulation, there may be the legal grounds for the dispositive legal regulation, and vice versa. The article also analyzes the ratio of the legal activity of an individual ("disposition") in criminal law and the development of society, using the example of a city. It is stated that the higher the legal activity of a person stipulated by law, the more secure is the position of a person in society.
\end{abstract}

\section{Introduction}

Necessity for the study of dispositivity in the Criminal law. There is no doubt that the Criminal Code in any country of the world is a document of paramount importance, and the existing Criminal Code of the Russian Federation apart from being important also seems to be a very progressive piece of legislation in modern Russia. However, a more detailed study allows coming to a rather paraxial conclusion. The main point of this conclusion is that the legislature has made a considerable step towards improving the

\footnotetext{
${ }^{*}$ Corresponding author: a.copytowa@yandex.ru
} 
situation of the delinquent (or the criminal), and these measures are of applied and specific (and hence real) character.

Undoubtedly, it is an important achievement of the Russian theory of criminal law. However as for the protection and enforcement of the rights of law-abiding citizens, the formulation of legislation tends to have a declarative nature. Among the main reasons of such a situation is the special commitment to Russian legislature traditions of the recent past and, above all, the idea of understanding the criminal law as a branch of public law only when "the state does not recognize anything private" [1, p. 9].

However, the legal activity of the individual, especially if it is provided by law, is one of the tools to ensure the safety of society in general and the individual, in particular. Accordingly, the analysis of the current criminal legislation in this part, as well as the formulation of relevant proposals for its improvement, seems relevant. In the article we will use dialectical, comparative legal and formal logical methods of research of social and legal phenomena.

The existing Criminal Code of the Russian Federation, the Criminal code of the Federal Republic of Germany and the Criminal code of Spain, and also materials of monographic researches and journal publications became the main source for writing of this article.

In the course of the research the main methods of knowledge have been used: problem and chronological, system and comparative jurisprudence. Reasonings of the author are under construction on the basis of problem and chronological approach. Application of a system method has allowed to integrate achievements of various branches of knowledge (the theory of the right, international law, constitutional right, criminal trial) into the criminal and legal doctrine and to formulate conclusions on the problems put in article. The method of comparative jurisprudence has allowed to illustrate a criminal and legal regulation of questions of ensuring interests of individuals in general and the victims, in particular, in Germany and Spain.

An individual's ability to implement his/her own rights (legal activity of the person) is associated with the category of "dispositivity" in the theory of law. This category has received a comprehensive development in the civil procedural law, as well as in research of criminal procedure in the last decade. The category of "dispositivity" is not typical and therefore was for a long time unacceptable for the criminal law due to the above-mentioned tradition. Moreover, it should be noted that A.V. Sumachev was the first to introduce the term "dispositivity" into the theoretical discourse of Russian criminal law [2, p. 20-21;3, p. 114-118; 4. p. 36-53].

The legislation analysis based on the studies of general theory of law and achievements of legal science representatives suggests that there is dispositivity in the field of criminal law regulation. It is well-known that de facto dispositivity occupies a worthy and significant place in domestic criminal law practice. However, the concept is recently being recognized as a legal phenomenon in the theory of criminal law. Moreover, the expansion of dispositivity has gained recognition as an important trend in the development of the Russian criminal law at the present stage [5, p. 27]. To develop the notion "dispositivity" further in the Russian criminal legal science above the level of ideas, it is necessary to develop a general legal framework and methodology of this phenomenon reflection in normative acts. This will create an effective mechanism to ensure the interests of individuals in the field of legal regulation.

It should be noted that foreign legislation describes issues of victims' interests' protection in detail. For example, the general part of German Criminal Code contains a specific chapter called "Complaint for Private Prosecution; Permission to Prosecute; Request to Prosecute; where the essential regulations are: "If an offence may only be prosecuted upon a request to prosecute, the victim may file the request unless the law provides otherwise" (§ 77); Request by a superior ( $\$ 77 \mathrm{a})$; “An offence which may only be 
prosecuted upon request shall not be prosecuted if the person entitled to file the request fails to do so before the expiry of a three-month period." ( $\$ 77 \mathrm{~b})$. In Special part of German Criminal Code the dispositivity of criminal prosecution is set for particular crimes. For example, defamation of the President of the Federation may only be prosecuted upon the permission of the President of the Federation; Anti-constitutional defamation of constitutional bodies may only be prosecuted upon the permission of the constitutional body or the member affected, etc. Besides, offences described in sections 123, 183, 185, 203, 223, 229 and 247 may only be prosecuted upon the victim's request [6].

Spanish Criminal Code also contains dispositive rules like: "Notwithstanding what is set forth in the preceding Article, valid free, conscious and specifically expressed consent shall exempt from criminal accountability in cases of organ transplant carried out pursuant to the terms of the Law, sterilisations and transsexual surgery carried out by a surgeon"(Article 156), "In felonies involving bodily harm, if valid, free, spontaneous consent is involved expressed by the victim, a punishment lower by one or two degrees shall be imposed"(Article 155) [7].

These are only particular examples of dispositivity in foreign criminal legislation. It should be noted that foreign legal and socio-legal practice suggests that the issues of victims ' interests protection transferred from the legal field to the functional activity.

In Russia it is a national tradition that shapes the regulatory and legal manner for deciding on most of socio-political issues. Due to this, the reflection of dispositive ideas in Russian criminal law is a necessary and timely task.

It should be specified that the term "dispositive" was introduced into legal science in the last decade, before that there was a similar term "private interest". It is distinctive not only for Russian science, but for the foreign studies too. For example, George Fletcher (USA) discourses about public and private aspects of penalty [8, p. 112-124], Helmut Frister reviews issues of justification in victims interest and how criminal prosecution should depend on victims intention [9, p. 240-242, 277-295, 393-396]. It appears that "dispositivity" is an "international" term which can be used in criminal law studies of any country.

Touching upon the problem of dispositivity in law in general, we can say that it mentioned in connection to some specific cases while normally the legislature merely states the fact of dispositivity existence. "Dispositivity" as a category is derived from the adjective "dispositive". In its turn, the term "dispositive" in legal science is used primarily in relation to the method of legal regulation (Y.A. Tikhomirov, V.D. Perevalov, I.N. Senyakina, N.I. Matuzov, V.I. Gaumann). Traditionally the legal science views dispositive method of regulation in three aspects: 1) presence of equal subjects of law (unsubordinated and independent); 2) presence of behavior alternatives provided by law; 3) choice of behavior variant depends on the will of the subject. The above stated components can serve as systemic elements of the category "dispositivity".

The concept of dispositivity. "Dispositivity" implies that the subject is not in the relationship "power - subordination" to another entity (entities). Not only an individual but also a social body (legal entity and even the state) can act as a legal entity. In addition, dispositivity implies that alternative norms of legal behavior are reflected in law, which provides for at least two variants of the possible behavior. Alternative behavior variants imply the possibility of choice. The choice means refusal from one and preference of another variant of a behavioral act. Refusal from certain variants of behavior should not lead to negative legal consequences for an entity (which is a kind of guarantee of freedom of choice prescribed by the law). Along with this the choice of behavioral variant depends on the legal entity 's will to exercise their own legitimate interest.

Analysis and generalization of "dispositivity" typical traits allow us to formulate the following concept: dispositivity is an opportunity granted by the state to independent 
unsubordinated legal entities to select at their own will alternative variants of behavior provided by law in order to satisfy the legitimate interests of these subjects. The choice of any behavior variant should not lead to negative legal consequences for the subject of law which serves as guarantee of dispositivity.

\section{Methods}

Dispositivity can be viewed from two different approaches: conceptual (political and legal) and instrumental.

Conceptual (political and legal) approach to the essence of dispositivity. From the point of conceptual (political and legal) approach dispositivity is treated as an idea of law, a general background of some field of legal regulation and a principle. The Russian legal reality in the last decade of the XXth century viewed dispositivity as a phenomenon stipulated by the achievements of democracy. Recognition of dispositivity as a legal phenomenon contributed to a drastic reform of national legislature. It stipulated the implementation of legal interests of individual as an independent entity and unsubordinated subject of law, including the relationship with the authorities. In this period the principle of dispositivity is reflected not only in civil law, but also in the branches of the Russian criminal law, mainly criminal procedural law.

Instrumental approach to the concept of dispositivity. In the framework of the instrumental approach dispositivity is treated as integral to the legal regulation method (Y.A. Tikhomirov, V.D. Perevalov, I.N. Senyakina, N.I. Matuzov, V.I. Gaumann, O.G. Perminov, E. L. Hilchuk), as property of legislation (L.Tikhomirov, M. Tikhomirov, A. Hajiyev), as a method of legal regulation (E.L. Sidorenko). The method of dispositive legal regulation is characterized by the following: firstly, the establishment, the termination or modification of relations between the subjects of law depends on the will of individuals and organizations to fully satisfy their own interests; secondly, the subjects of law are equal and independent from each other (they are not in a relationship of "power - submission"); thirdly, the implementation of rights and duties of legal entities can be guaranteed without recourse to the authority.

The typical features of dispositive legal regulation method are expressed as the following:

1. The scope of what is permitted by law among the behavior alternatives is stipulated by the possibility of choice to satisfy one`s own interest. Any type of legal regulation provides an opportunity to choose: both permissive (everything which is not explicitly prohibited is permitted) and restrictive (everything which is not explicitly permitted is prohibited).

2. The following dispositive legal norms are accepted: a) those providing alternative behavior variants (in this case a dispositive legal norm may contain general permission, a full list of possible behaviors or a certain variant of behavior, defined by the legislator which logically stipulates other possible behavior alternatives); b) the choice of behavior variant depends on the subject's will, which tends to fully satisfy one's own interest; c) safety from negative consequences for the subject of law in case of free choice of behavior. The body of dispositive norms can form a dispositive legal institution, which is not merely a collection of dispositive norms but it includes binding norms and guarantees without changing the dispositive nature of the institution.

3. Subjects of relations are granted legal capacity that allows them to enter into legal relations.

4. The measures of responsibility in the case of "withdrawal" of legal entities are determined beyond regulated relationships. 


\section{Results}

The prove of dispositivity in the Russian criminal law. While trying to determine the role of dispositivity in the Russian law through the balance of private law and public law we can say that there is no definite distinction between these branches of law. Concepts and ideas of private law and public law stipulate political and legal views on the position of individual in the state. These concepts are applied in the professional sphere to determine the subject and method of legal regulation.

The balance between private and public law is translated into separate branches of law from the perspective of ideas and concepts. Since the subject and method of law act as the principle of division between legal spheres then private or public nature of legal concepts or methods define the nature or type of a particular legal sphere. However, in a typical field of legal regulation there can be a non-typical area (so termed "autonomous" by S.S. Alekseev, who claims that "prohibitions, permission, obligations in this area can be of a one-time or individual nature") [10, p. 61]. In other words, the spheres characterized by imperative method of legal regulation can include legal relations regulated by the dispositive method and vice versa.

It should be noted that the development of dispositive ideas in the Russian criminal law at the initial stage of the Russian state history was determined by two equivalent factors. On the one hand there was strengthening of state power, which brought elements of publicity into the legal practice, on the other hand it was following the traditions and customs of the legal regulation that led to preservation of private component in law. Later strengthening publicity in law became the dominant idea.

Strengthening and centralization of state power (medieval absolutism, socialism) has determined the state monopoly in legal regulation without recognizing dispositivity even as a legal phenomenon. State perception of natural law ideas in the XIX - early XX centuries and in the post-Soviet period in Russia serves to the fact that punishability or nonpunishability for some crimes depends on the individual's (victim) will in the framework of the criminal law. Dispositivity in the Russian science is recognized as a legal phenomenon that should be inherent in the national criminal law. Due to the natural law theory which underlies the legal reform, dispositive ideas are reflected in the Russian criminal law.

Currently, many researchers agree that dispositivity is a legal phenomenon, which dictates that an individual in the field of legal regulation should be recognized as an active subject of law (B.V. Volzhenkin, V. Mikhailov, N.I. Korzhansky, A.N. Krassikov, S.V. Parkhomenko, T.G. Ponyatovskaya, B.A. Protchenko, S.V. Rastoropen, E.L. Sidorenko, E.S.Tench, etc.). Legislative innovations of the Criminal Code of the Russian Federation (Article 76, the note to Article 122, the note to Article 134, the note to Article 201 of the Criminal Code) confirm the influence of dispositive ideas on Russian criminal policy and criminal law-making. However, despite this, we can say that the instrumental approach to the analysis of dispositivity in the criminal law has not been thoroughly developed.

Transfer of theoretical grounds of dispositive method to the criminal legal sphere allows to state the following:

1. Criminal law is a permissive type of legal regulation when a general prohibition corresponds to specific permissions. Criminal law provides permission for legal subjects (individuals or organizations), which can be roughly classified according to the addressee: the permission addressed to law-abiding individuals (art. 37-42, 76, notes to Art. 122, 134 and 201 of the Criminal Code) and permission addressed to a person committing or who has committed a crime (Article 31, paragraph "i" , "j" Part 1 of Art . 61, Art. 75, notes to Art. 126, 127-1 , 204, 205 , 205 - 1 , 206, 208 , 210, 222, 223 , 228, 275, 281-1 , 282-2 , 291, 307 of the Criminal Code ). 
2. The criminal law includes dispositive legal norms. These norms do not include voluntary abandonment of intention to commit a crime or active repentance since committing a crime while having the opportunity to stop from committing the crime leads to criminal liability. Also, unwillingness to repent in committing a crime results in sanctions provided by the Criminal Code. This is not peculiar for dispositive norms. Besides, the dispositive norms stated in the Criminal Code of RF lack general concepts and/or rules (for example, notes to Art. 122 and notes to Art. 134 of the Criminal Code ) being unsystematic (e.g., Art. 76, notes to Art. 201 of the Criminal Code). That is why today we can speak of existing dispositive norms in the Russian criminal law but not of dispositive legal institutions.

3. Special features of granting subjects of law the legal capacity in dispositive framework are stipulated by the nature of permissions. Thus, the right to personal injury for purposes of self-defense applies to persons of any age, while the right to reconciliation applies to an adult.

4. The Criminal Law identifies certain permissions and provides guarantees of compliance with these permissions for subjects of law (the law defines responsibility for specific cases of exceeding the limits of necessary defense, for inflicting punishment and lynching by the victim instead of reconciliation, if such punishment contains elements of a crime).

1) Accordingly, the dispositive method is used in the field of legal regulation in the following cases: 1) when the occurrence, termination or modification of relations between subjects of law depends on the will of individuals and organizations in order to satisfy their legitimate interests (this category does not include persons who commit or committed a crime - "criminals" or "potential criminals"); 2) when the subjects are independent of each other, even despite the fact that the legal relationship in criminal law implies a compulsory subject of law which is the State (e.g., the criminal relationship between the victim and the state in resolving the conflict through the criminal reconciliation between the victim and the delinquent); 3) when the implementation of the rights and duties of subjects of law can be achieved without recourse to government entity, such as the State (for example, by selfdefense against socially dangerous attack).

\section{Discussion}

Dispositivity practices in the Russian criminal law. Investigation of specific forms of dispositivity in the present-day criminal law in Russia suggests that not all permissions addressed to law-abiding individuals are dispositive.

Thus, self-defense is one of the forms of dispositivity only if there is a possibility for the individual in the state of self-defense to avoid a dangerous attack, or seek help from other people or authorities. Alternative variants of behavior here are the possibility to inflict harm to the attacker and to avoid attack while the choice of behavior depends on the will of the individual in self-defense who seeks to "come out" of it with the least damage to himself. The choice of one variant of behavior and refusal from the other should not lead to negative legal consequences for the individual.

Detention of a person who committed a crime is a form of dispositivity only when detention is the right of an individual rather than the duty of the authorized official representative (for example, the duty of a police officer).

Reasonable risk is one of the manifestations of dispositivity, since the subject who takes the risk has always the alternative of choice (V.I. Samarokov, I.M. Tyazhkova, S. Zakharov). The choice of some variant of behavior by the subject taking risk (by a test subject in case of experimental risk) depends solely on the subject's will. Refusal from risky actions may not result in negative legal consequences for any of the subjects. 
Reconciliation is considered to be a form of manifestation of dispositivity only from the position of the injured party.

Criminal prosecution at the request or consent of a commercial organization or in case of damage to the interests of this organization under Chapter 23 of the Criminal Code is also a form of dispositivity in the present-day criminal law of Russia.

A form of dispositivity in the present-day criminal law of Russia is the consent of a person to action which causes the person a danger for HIV infection (notes to Art. 122 of the Criminal Code), as well as the victim`s consent to enter into marriage with the accused (note to Art. 134 of the Criminal Code).

Absolute necessity, physical or mental abuse, as well as the execution of an order or orders, despite the fact that they provide for the permission to inflict harm cannot be considered the manifestations of dispositivity in criminal law.

\section{Conclusion}

The study of the dispositivity problem in Russian criminal law is due to a number of factors:

1) the development and reflection of dispositivity principles in criminal law testifies to the level of protection of law-abiding citizens of the state, and equally serves as an indicator of the legal activity of an individual in the field of criminal justice;

2) Until recently (until the adoption of the Criminal Code of the Russian Federation in 1996), the Russian legislator adhered to the traditions of Soviet criminal law, where "the state does not recognize anything private";

3) The modern criminal legislation of individual foreign countries regulates in detail the issues of ensuring the interests of victims in the field of criminal law regulation;

4) The "dispositivity" category has an "international" character and can be used in scientific research of the branches of the criminal cycle of all states

In the most general sense, dispositivity can be viewed as the guarantee by the state for independent legal subjects to choose the most suitable variant of lawful behavior provided by which most fully contributes to the legitimate interests of these subjects.

As a part of the conceptual (political and legal) approach dispositivity should be considered as the concept of law, the common grounds of legal regulation or a basic principle.

As a part of the instrumental approach dispositivity can be considered as a method of legal regulation, the property of legal norms or as a mode of legal regulation.

We can talk of dispositivity in the Russian criminal law from the point of legal methodology since there are no "pure" branches of private or public law. Simultaneously the legal regulation can be guided by the imperative method with the elements of dispositive legal method, and vice versa.

Practical legal aspect allows for the following forms of dispositivity in the Russian criminal law:

1) self-defense (but only if the individual in the state of self-defense has the possibility to avoid socially dangerous attacks or able to ask for help from other people or authorities);

2) detention of a person who has committed a crime (only if detention is a right of an individual, rather than a legal obligation of specifically authorized representative of authority);

3) a reasonable risk;

4) reconciliation (but only from the part of free will of the injured party);

5) criminal prosecution at the request of a commercial organization or with its consent in cases of damage to the interests of the organization under Chapter 23 of the Criminal Code; 
6) consent of a person to action which has a potential risk for HIV infection (note to Art. 122 of the Criminal Code);

7) consent of the victim to enter into marriage with the defendant (note to Art. 134 of the Criminal Code).

These are obviously the main provisions that characterize the concept of individual's legal activity in the field of criminal regulation which is called the dispositivity in the criminal law.

And in conclusion, we can note that this study was carried out within the framework of the activities of the scientific school of the Ugra State University "Scientific support of the effectiveness of the implementation of modern criminal law policy of the Russian Federation: criminal law and criminological directions", and is focused on the legal support of the legal activity of the individual ("dispositivity") in criminal law in order to ensure the safe position of a person in society.

\section{References}

1. B. Mankovsky, The situation at the frontline of the socialist theory of Criminal law (Moscow, 1938)

2. A.V. Sumachev, Dispositive fundamentals in the German criminal law (Tyumen, 2001)

3. A.V. Sumachev, Dispositivity in the criminal law: stating the problem, Reports of the Russian practice-oriented conference (Ufa, 2001)

4. A.V. Sumachev, Concerning dispositivity in the criminal law (Moscow, 2001)

5. G. Fletcher, A.V. Naumov, Basic Concepts of modern Criminal Law (Moscow, 1998)

6. H. Frister, German Criminal Law. General Part (Moscow, 2013)

7. S.S. Alexeev, General permissions and prohibitions in Soviet Law (Moscow, 1989) 